\title{
A COMPARATIVE STUDY FOR THE PROGRESSIVE FAILURE ANALYSIS OF DOUBLE- NOTCHED GLASS/EPOXY COMPOSITE LAMINATES
}

\author{
DINH CHI PHAM \\ Institute of High Performance Computing, $A *$ STAR \\ 1 Fusionopolis Way, \#16-16, Connexis, Singapore 138632 \\ phamdc@ihpc.a-star.edu.sg
}

\begin{abstract}
This work presents a comparative study for the progressive damage analysis of double-notched glass/epoxy composites with layups $[90 / 0]_{\mathrm{s}}$ and $[45 / 90 /-45 / 0]_{\mathrm{s}}$. The material property degradation method (MPDM) is used to model the intra-lamina failure whereas cohesive elements (CE) are employed to account for the delamination at the interfaces. Different fracture mechanicsbased and continuum damage mechanics-based failure theories are considered in the MPDM-CE approach and a comparative study of these failure theories is presented. The predictions are compared with the experimental results reported by Hallett and Wisnom [2006]. Reasonably good agreement between experiment results and simulation results is obtained, showing that the MPDM-CE approach can effectively predict the progressive failure in double-notched glass/epoxy composite laminates. Furthermore, it is significantly revealed that a modification scheme for the progressive failure modeling of fiber failure may be necessary to improve the strength prediction of notched composites.
\end{abstract}

Keywords: progressive failure; double-notched composite; material property degradation method (MPDM); cohesive element, failure criterion.

\section{References}

Barbero, E.J. and Lonetti, P. [2002], “An Inelastic Damage Model for Fiber Reinforced Laminates”, Journal of Composite Materials 36(2002), 941-962.

Barenblatt, G.I. [1962], "Mathematical Theory of Equilibrium Cracks in Brittle Failure", Advances in Applied Mechanics 7(1962), 55-129.

Brewer, J.C. and Lagace, P.L. [1988], "Quadratic Stress Criterion for Initiation of Delamination”, Journal of Composite Materials 22(1988), 1141-1155.

Camanho, P.P., Bowron, S. and Matthews, F.L. [1998], "Failure Mechanisms in Bolted CFRP”, Journal of Reinforced Plastics and Composites 17(1998), 205-233.

Camanho, P.P., Davila, C.G. and Ambur, D.R. [2001], "Numerical Simulation of Delamination Growth in Composite Materials", NASA-TP-211041 (2001).

Chang, F.K., Lessard, L. and Tang, J.M. [1988], “Compression Response of Laminated Composites Containing an Open Hole”, SAMPE Quartely 19(1988), 46-51.

Christensen, R. M. [1997], "Stress Based Yield/Failure Criteria for Fiber Composites," International Journal of Solids Structures 34(1997), 529-543.

Christensen, R. M. and DeTeresa, S.J. [2002], "Failure Plane Orientations for Fiber Composites", American Society for Composites $17^{\text {th }}$ Technical Conference, West Lafayette, IN (2002).

Christensen, R.M [2008]. "Failure Criteria for Anisotropic Fiber Composite Materials", http://www.failurecriteria.com (2008)

Daniel, I.M. [2007], "Failure of Composite Materials", Strain 43(2007), 4-12.

Dugdale, D.S. [1960], "Yielding of Steel Sheets Containing Slits", Journal of Mechanics and Physics of Solids 8(1960), 100104.

Feih, S. and Shercliff, H.R. [2005], "Adhesive and composite failure prediction of single-L joint structures under tensile loading", International Journal of Adhesion and Adhesives 25(2005), 47-59.

Greif, R. and Chapon, E., "Investigation of Successive Failure Modes in Graphite/Epoxy Laminated Composite Beams", Journal of Reinforced Plastics and Composites 12(1993), 602-620.

Ha, S.K., Jin, K.K. and Huang, Y. [2008], "Micro-Mechanics of Failure (MMF) for Continuous Fiber Reinforced Composites", Journal of Composite Materials 42(2008), 1873-1895.

Hallett, S.R. and Wisnom, M.R. [2006], "Experimental Investigation of Progressive Damage and the Effect of Layup in Notched Tensile Tests”, Journal of Composite Materials 40(2006), 119-141. 
Hinton, M.J., Kaddour, A.S. and Soden P.D. [2002], "A Comparison of the Predictive Capabilities of Current Failure Theories for Composite Laminates, Judged against Experimental Evidence", Composites Science and Technology 62(2002), 1725-1797.

Hinton, M.J., Soden, P.D. and Kaddour A.S. [2004], "Failure Criteria in Fiber-Reinforced-Polymer Composites", Elsevier, Oxford (2004).

Hou, J.P. et al. [2000], "Prediction of Impact Damage in Composite Plates", Composites Science and Technology 60(2000), 273-281.

Icardi, U., et al. [2007], "Assessment of Recent Theories for Predicting Failure of Composite Laminates", Applied Mechanics Reviews 60(2007), 76-86.

Kim, Y., Davalos, J.F., and Barbero, E.J., "Progressive Failure Analysis of Laminated Composite Beams", Journal of Composite Materials 30(1996), 536-560.

Kortschot, M.T. and Beaumont, P.W.R. [1990], "Damage mechanics of composite materials: II-- a damaged-based notched strength model”, Composites Science and Technology 39(1990), 303-326.

Kwon, Y.W. and Craugh, L.E. [2001], "Progressive Failure Modeling in Notched Cross-Ply Fibrous Composites". Applied Composite Materials 8(2001), 63-74.

Kwon, Y.W. and Craugh, L.E. [2001], "Progressive Failure Modeling in Notched Cross-Ply Fibrous Composites", Applied Composite Materials 8(2001), 63-74.

Ladeveze, P. and Dantec, E. Le [1992], "Damage Modeling of the Elementary Ply for Laminated Composites", Composites Science and Technology 43(1992), 257-267.

Ladevèze, P. et al. [2000], “A Mesomodel for Localisation and Damage Computation in Laminates”, Computer Methods in Applied Mechanics and Engineering 183(2000), 105-122.

Liu, K.S. and Tsai, S.W., “A Progressive Quadratic Failure Criterion for a Laminate”, Composites Science and Technology 58(1998), 1023-1032.

Petrossian, Z. and Wisnom, M.R. [1998], "Prediction of Delamination Initiation and Growth from Discontinuous Plies Using Interface Elements", Composites Part A 29(1998), 503-515.

Pham, D.C. [2011], "Progressive failure analysis of double-notched composite laminates", PhD thesis, National University of Singapore, 2011.

Pham, D.C. and Sun, X.S. [2012], "Experimental and computational studies on progressive failure analysis of notched crossply CFRP composite", International Journal of Computational Materials Science and Engineering 1 (2012), 1-15.

Tan, S.C. [1991], “A Progressive Failure Model for Composite Laminates Containing Openings", Journal of Composite Materials 25(1991), 556-577.

Tan, S.C. and Nuismer, R.J. [1989], “A Theory for Progressive Matrix Cracking in Composite Laminate”, Journal of Composite Materials 23(1989), 1029-1047.

Tan, S.C. and Perez, J. [1993], "Progressive Failure of Laminated Composites with a Hole under Compressive Loading", Journal of Reinforced Plastics and Composites 12(1993), 1043-1057.

Tay, T.E., Liu, G., Tan, V.B.C., Sun, X.S. and Pham, D.C. [2008], "Progressive Failure Analysis of Composites", Journal of Composite Materials 42 (1008), 1921-1966.

Tsai, S.W editor [2008], "Strength and Life of Composites", Aeronautics and Astronautics, Stanford University, CA $94305-$ 4035 (2008).

Tsai, S.W. and Wu, E.M. [1971], “A General Theory of Strength for Anisotropic Materials”, Journal of Composite Materials 5(1971), 58-80.

Ye, J. and Zhang, D. [2012], "Prediction of failure envelopes and stress-strain curves of fiber composite laminates under triaxial loads", Journal of Composite Materials (2012), 0021998312449678 